\title{
THE VOTER REALIGNMENT IN THE MIDWEST DURING THE 1850s
}

\author{
RAY M. SHORTRIDGE \\ University of Michigan
}

merican voting patterns exhibit long periods of relative
stability in the voters' partisan preferences. This continuity, however, is occasionally interrupted by a sudden shift in party loyalties. This inquiry focuses on the shift of party loyalties in the 1850s which gave rise to the Republican party. During the $1850 \mathrm{~s}$, the national party system underwent a massive reorganization. At the beginning of the decade, the Democrats and the Whigs were the major contenders for national political power, and the Democracy enjoyed dominance. A third party, the Free Soil, experienced limited success in the North. At the end of the decade, both the Whig party and the Free Soil party had vanished. A fourth party, the nativistic American, had emerged to contest the 1856 Presidential election, but it, too, had essentially disappeared from the Northern political scene by 1860 . Only the Democracy survived the decade. A dynamic new element in American politics, the Republican party, contested the 1856 campaign and won the electoral votes of the six New England states, New York, Ohio, Michigan, Wisconsin, and Iowa. The 1860 election brought triumph to the new party as the Republicans swept the

Author's Note: This paper has benefited from the criticisms made by Mr. Eric Austin and Professors Jerome Clubb, Shaw Livermore, Jr., and John Sharpless. 
Northern states and elected Abraham Lincoln President of the United States. To obtain a clearer view of the realignment, this study examines the flow of the vote among the political parties in the Midwest through the 1850s.

\section{CRITICAL REALIGNMENTS AND AMERICAN POLITICS IN THE 1850s}

Critical realignments apparently occur infrequently because most voters develop a strong psychological attachment to one of the contending parties which moves them to vote regularly for it over a number of elections (Campbell, Gurin, and Miller, 1954; Campbell, Converse, Miller, and Stokes, 1960; Eulau and Schneider, 1956). People who identify with a party tend to vote for it regularly, despite changes in the issues at stake and the slates of candidates pursuing public office. In part, regular voting arises because identifiers are disposed to cast their ballots for the favored party even before the election campaign begins. This inclination is sustained during the campaign because the citizens' sense of identity with a party colors their perception of the candidates and issues. People who identify with a party are prepared to approve of their party's nominees and to suspect the opposition's candidates; they accept their party's stand on the issues and reject the positions adopted by the opposition (Berelson, Lazarsfeld, and McPhee, 1954; Belknap and Campbell, 1951-1952; Converse and Dupeux, 1967). Although the circumstances unique to a campaign occasionally prompt some members of the "party-in-the-electorate" (Key, 1953: 181 ) to vote for its rival, the defection is usually short-lived and does not involve a shift in party identification (Converse, Campbell, Miller, and Stokes, 1961). As a consequence, the occasions when the electoral bedrock of the Republic shifts are extraordinary events. Indeed, the electorate has undergone sudden realignment on a massive scale only three times since the second national two-party system emerged during the Jackson and Van Buren administrations: in the 1850s; in the 1890s; and 
in the 1930s (Lowi, 1967). The rarity of these events and the attendant political significance warrant an intensive investigation of the process of electoral realignments (for a discussion of electoral realignments see Sundquist, 1973: 1-38; Key, 1955: 1-18; Burnham, 1970: 1-10; Burnham, Clubb, and Flanigan, 1973).

One general view of major realignments contends that they occurred when an issue, urgent and vital to a large number of the citizens, intruded to cut across the existing partisan ties (Sundquist, 1973: 1-38). This characterization contains two essential points. First, for a pressing issue to trigger a realignment, it must arouse strong disagreement among the voters. If there is great concern but little disagreement (an attack by a foreign power, for example), then the voters need not shift their partisan preferences. Second, each party must contain sizable blocs of the antagonists for the realignment to assume major proportions. If the fracture created by the new issue parallels that of the existing alignment-that is, if most pros are in one party and most cons are in the other-then the existing alignment can accommodate the strain introduced by the new issue with only a few voters switching their party loyalties. When a crucial issue bursts upon the political scene and produces dissensions within each party, then the stage is set for a major realignment of the electorate.

This cross-cutting issue model of a realignment, in which regular voting patterns are disrupted by a salient political question, is usually found in the mainstream political histories of the 1850s. The political narratives typically depict a stable electoral alignment between the Whig and Democratic parties being destroyed by the sudden intrusion of the slavery expansion issue (see, e.g., Filler, 1960; Smith, 1967; Nevins, 1947). National politics from the time of Andrew Jackson's presidency until the 1854 election revolved around the contest for office between Whig and Democratic politicians. Minor parties (notably the Liberty and later the Free Soil parties) competed for the electorate's votes, but the central question 
posed by the campaigns of the day was whether Whigs or Democrats would rule. Although the attitudes underlying the Democrat-Whig voter alignment have yet to be firmly established, historians have detected substantial differences between the party leaders' views on a variety of issues ranging from the proper role of the government in the economy to a general disposition towards reform (Ershkowitz and Shade, 1971). Studies of nineteenth-century voting patterns also suggest that ethnic and religious differences underlay many voters' party preference (Benson, 1967; Formisano, 1971). For whatever reason, however, the individual voter throughout this period apparently aligned himself with one of the parties because the electorate evidenced considerable stability in party choice (Shortridge, 1974).

The literature describes the shattering impact of the slavery extension issue on the voter alignment of the Democrat-Whig system. During this period, the question of slavery had been excluded from partisan controversy by the leaders of the two major parties. However, the disposition of vast territory won during the war with Mexico reintroduced slavery into politics, and the nation was staggered by the crisis. It seemed that resolution was achieved with the Compromise of 1850 . Then, four years later, the North was shocked when the Democratic party leaders violated the Compromise of 1820 by pushing the Kansas-Nebraska bill through Congress. This bill opened the territories to slavery by permitting slaveholders to settle in the land north of the southern boundary of Missouri. Immediately, the political rhetoric became centered upon the slavery extension issue, and the political consciousness of the American public was assaulted with inflammatory denunciations, apologias, charges, and counter-charges-all designed to persuade the citizen that the fate of democracy, or of a salubrious society, or of one's own immediate interests was bound up in the resolution of the slavery question. Political histories of the period typically reflect this preoccupation with slavery, painstakingly tracing the origins of the anti-slavery political move- 
ment and describing the anti-slavery campaigning of the Republican party. According to this view, the Kansas-Nebraska bill, bleeding Kansas, and the Dred Scott decision impelled an outraged Northern public to flock to the Republican banner. Within six years, the Democracy had lost its hegemony to the new Republican party.

The new Republican party was organized explicitly to combat the extension of slavery into the Nebraska Territory. The sectional appeal of the Republicans was a feasible strategy for acquiring control of the national government because Northern states possessed more than half of the votes in the Electoral College. Republican strategists saw that they could capture the Presidency and the House of Representatives without any Southern support if they could attain hegemony over the North. However, to win in the North, the Republican party had to defeat the formidable Democratic party in virtually every state. In 1852 , the Democratic party received $49.9 \%$ of the vote while carrying 416 of the $612(68.0 \%)$ of the Northern counties, while its principal adversary, the Whig party, attracted $43.6 \%$ of the vote. ${ }^{1}$ In short, the Republican strategy envisaged, indeed required, a major realignment among the Northern electorate-a shift of many Northern voters to the Republican party. The strategy succeeded. In the 1856 Presidential election, the Republicans received $46.3 \%$ of the vote cast in the Northern states while the Democrats received $41.1 \%$. In 1860 , Lincoln led his party to victory by garnering $54.6 \%$ of the vote cast and carrying 490 of the 703 counties $(69.7 \%)$ in these states. The Republican ascendancy in the North commenced during this realignment period and prevailed in Presidential elections for the remainder of the century.

Where did the Republicans obtain the votes which made them the dominant party in the North? The search for an answer is eased by the fact that, at that time, the Midwest had only a limited number of voter reservoirs: (1) people who voted Democrat in 1852 ; (2) people who voted Free Soil in 1852 ; (3) people who voted Whig in 1852 ; (4) people who abstained in 
1852; (5) and people who were ineligible to vote in 1852. Individuals from each of these groups undoubtedly moved into the Republican fold. Hence, a crucial issue lies in assessing the tendency of people in each of these categories to vote Republican in subsequent elections-that is, measuring the proportion of each group which later cast Republican ballots. This analytical approach breaks down the large question regarding the origins of the Republican votes into a few more focused inquiries: Did a large proportion of Democrats cross over to the Republican party? Did a fusion process coalesce Whigs and Free Soilers into the new party? Did the Republicans mobilize many heretofore nonvoters into their constituency? Finally, did the realignment occur in a single election or extend over a series of elections? ${ }^{2}$

The typical presentation of the period suggests that the furor over the slavery extension issue disoriented considerable numbers of people and dislodged them from their previous party loyalties. In particular, the histories lead one to suspect that many Northern Democrats defected to the Republicans. Eric Foner, for example, in his penetrating study of the Republican ideology, contends that the Republicans attracted the support of a significant number of rank-and-file Democrats (Foner, 1970: 149-185; Sundquist, 1973: 39-91). Yet, the margin needed for a Republican victory was not so great as to require massive defections from the Democracy. An equally plausible hypothesis is that the Republican party drew support from disparate groups within the electorate who were outside the Democratic fold-Whigs who had nowhere else to go; Free Soilers who would be attracted by the Republican party's unequivocal stand against the expansion of slavery; and those who previously had not voted regularly in national elections. By cementing these blocs of voters together into a new political coalition, the Republicans could amass a triumphant electoral majority. 


\section{THE SCOPE AND PROCEDURES OF THE STUDY}

The inquiry focuses on four Midwestern states-Illinois, Indiana, Michigan, and Ohio-for a number of reasons. First, the region contained a large segment of the North's population since over a third of the votes cast in the North during this period were cast in these four states. Second, the WhigDemocrat two-party system was deeply rooted; together these two major parties consistently polled $90 \%$ or more of the vote cast in Presidential elections from 1840 through 1852. Moreover, the reorganization of the Midwestern party system during the 1850 s paralleled the process occurring elsewhere in the North. In 1852, the Democracy garnered $49.9 \%$ of the vote in these states compared with the Whig's $42.9 \%$. The Republicans and Democrats closely contested the 1856 election with both parties receiving about $45 \%$ of the vote cast. In 1860 , the Republicans soundly defeated the Democrats in these states, $52.2 \%$ to $43.6 \%$. These particular Midwestern states were selected because they held elections throughout the WhigDemocrat years, 1840-1852. The new Midwestern states, such as Iowa or Wisconsin, were not in the Union during much of that period and hence have a more abbreviated temporal span over which the electorate's voting patterns can be examined. Finally, the statistical techniques used in the inquiry require that a substantial number of counties be included in the analysis. For this period, the analysis draws upon about 90 counties in Illinois, Indiana, and Ohio and about 35 in Michigan, or a total of more than 300 counties for the four states. Because the new states contained only a few thickly settled counties at this time, one can have only limited confidence in the estimates produced by the statistical procedures. However, the electorates in Illinois, Indiana, Michigan, and Ohio cast $82.5 \%$ of the votes recorded in the Midwest in the 1856 Presidential election; this suggests that excluding the newer Midwestern states does not seriously reduce the generality of the findings. 
In 1852, the Presidential year immediately preceding the formation of the Republican party, the Midwestern electorate faced four possibilities: casting a Democratic ballot; casting a Whig ballot; casting a Free soil ballot; or abstaining. The 1856 Presidential election posed four choices: voting Democrat, Republican, American or abstaining. Although three parties campaigned in the Midwest in 1860, so few people cast ballots for the Union party that the real options for the electorate seem to have been voting Democrat or Republican or abstaining. A systematic examination of the realignment process for this period entails observing the subsequent choices made by the supporters of both the major and minor political parties and also the subsequent actions of those who abstained in a particular election.

Ideally, the flow of the vote during the realignment would be examined by observing the choices made by individual voters in successive elections. However, only a few records containing the voting choices made by individual citizens survive, mostly in the form of poll books in which the publicly announced choice of each voter was recorded. However, during the first few decades of the nineteenth century, voting by ballot generally superseded viva voce voting. By 1840 , the use of poll books was no longer the common practice in the Midwest, although Illinois persisted in the anachronistic practice until 1849 . Hence, an inquiry into the flow of the vote must employ aggregate election data rather than individual voting records for the realignment period. The aggregate data have an advantage in that they comprehensively cover the general voting population for the four states.

This study analyzes election data aggregated at the county level and infers the patterns for individuals from that county level information. Specifically, the variables in the analysis consist of the proportion of the estimated eligible voting population which voted for each party-called party turnoutand the proportion which abstained in Presidential elections between 1840 and 1860. Party turnout was computed by dividing the number of votes cast for the party by the number 
of eligible voters estimated to have been living in a county during the election. Public records, of course, report the number of ballots cast for each party in an election, but they do not contain a count for the size of the eligible voting population. Consequently, the number of eligible voters had to be estimated from the United States Census. The number of white adult males enumerated by the census was used as the estimate for the eligible voting population for the census years, with the number for intercensus years calculated by linear interpolation. ${ }^{3}$

Using aggregate data to infer individual level behavior raises the issue of the "ecological fallacy." The ecological fallacy is the assumption that the zero-order correlation calculated for a distribution of counties (or other areal unit) along two variables accurately measures the association between the variables among the individuals within those counties (Robinson, 1950; Alker, 1969: 101-106). Since the ecological fallacy was initially discussed, a number of procedures for obtaining less specious estimates have been developed (Duncan and Davis, 1953; Converse, 1969). This analysis employs the coefficients obtained from "ecological regression" to estimate the individual level patterns (Goodman, 1953, 1959).

As an example, in this study ecological regression may entail regressing the party turnout for the Republican slate in an election on the party turnout for the Republican ticket in the previous election across a set of counties. The coefficients are then used to estimate the proportion of Republican voters of the first election who cast Republican ballots in the second in the area encompassed by the counties. The following equation represents this procedure:

$$
\bar{Y}_{j}=b_{0}+b_{e} \bar{X}_{1 j}+E_{j}
$$

where (as in the example) $\overline{\mathrm{Y}}_{\mathrm{j}}$ is the Republican turnout in time two in the $j$-th county, $b_{0}$ is the intercept, $b_{e}$ is the coefficient for $\bar{X}_{1 j}$, the Republican turnout in time one in the $\mathrm{j}$-th county, 
and $E_{j}$ is the residual for the $j$-th county. The intercept is an estimate for the proportion of non-Republicans in the first election who change their behavior by voting Republican in the next election. The sum of the intercept and the coefficient, $b_{e}$, is an estimate for the proportion of the Republican voters in the first election who again cast a Republican ballot in the subsequent election. One may substitute the Democratic percentages for $\overline{\mathrm{X}}_{1}$ and obtain estimates for the proportion of Democrats who switched to the Republicans in the second election. The percentages produced by the regressions are measuring proportions of the statewide electorate. To control for the disproportionate impact which a few sparsely settled counties might have on the estimates, a parallel analysis was performed in which the units were weighted by population density. There was, however, little difference observed between the weighted and unweighted estimates. To facilitate a parsimonious display of the data, the tables present only the unweighted estimates.

Use of this estimating model entails several assumptions about the world being described. First of all, one must assume that there are no aggregate level effects. The necessity for this assumption can be appreciated by examining equation 2 , which presents the regression model that could be used if both individual and aggregate level data were available.

$$
Y_{i_{j}}=b_{0}+b_{1} \bar{X}_{i_{j}}+b_{2} X_{i_{j}}+b_{3} X_{i_{j}} \bar{X}_{i_{j}}+E_{i_{j}}
$$

Within the context of this study, $Y_{i_{j}}$ indicates whether the individual voted Republican in an election; $b_{0}$ is the intercept; $b_{1}$ is the coefficient for $\bar{X}_{i_{j}}$, the Republican turnout in the previous election; $b_{2}$ is the coefficient for $X_{i_{j}}$, whether the $i-t h$ person voted Republican in the previous election; $b_{3}$ is the coefficient for $X_{i_{j}} \bar{X}_{i_{j}}$, the interactive term; and $E$ is the residual.

The coefficient for the interactive term in the complete data model, $b_{3}$, can be estimated by introducing an exponential 
variable in the ecological regression equation which is the square of the party turnout for each county. ${ }^{4}$ The coefficients for this exponential term were generally trivial, indicating that there was little influence on party choice in an election by the interaction between party choice and party strength in the preceding election. There is no way, unfortunately, to obtain separate measures for the aggregate level and individual level coefficients produced by the complete data model from the ecological regression model. This complete data model produces discrete measures for the influence of individual and aggregate factors (the regression coefficients $b_{1}$ and $b_{2}$ ). However, the ecological regression model produces only one coefficient, $b_{e}$, which is assumed to be the coefficient for the individual level effect, $b_{2}$, in the complete data model (Boyd, 1971). For $b_{e}$ to equal $b_{2}$, one must assume that $b_{1}$ equals zero-that is, no aggregate level effect.

Use of the ecological regression procedure to estimate the transitional probabilities of party choice from one election to another violates the assumption that the population was closed. The electorate within the counties obviously changed from year to year because some of the people present during the first campaign died or moved by the second campaign and some of those present during the second campaign attained their majority or moved into the area subsequent to the first campaign. Violating the closed population assumption introduces random variation into the bivariate distribution for the party turnout levels recorded for the counties in successive elections. The effect of this artifactual variation is to bias the intercept towards the mean party turnout computed for the counties and to bias the ecological regression coefficient towards zero. These biases tend to minimize differences in the subsequent party choice between the electoral groups. The presence of a conservative bias in the estimates serves to increase the confidence one has in any differences which emerge in the analysis. 


\section{THE REALIGNMENT: DEMOCRATIC COHESION}

Political histories of the 1850s typically depict the Democratic electoral majority crumbling under the repeated pro-slavery blows administered by the party's own leadership. Yet the evidence from the election records suggests that the Democratic party continued to receive voting support from a large proportion of the electorate during the slavery expansion controversy. As Figure 1 shows, in 1856 and 1860 (the campaigns waged during the height of the slavery controversy) the proportion of the electorate voting Democrat matched that garnered by Democratic slates in 1848 and 1852. The election

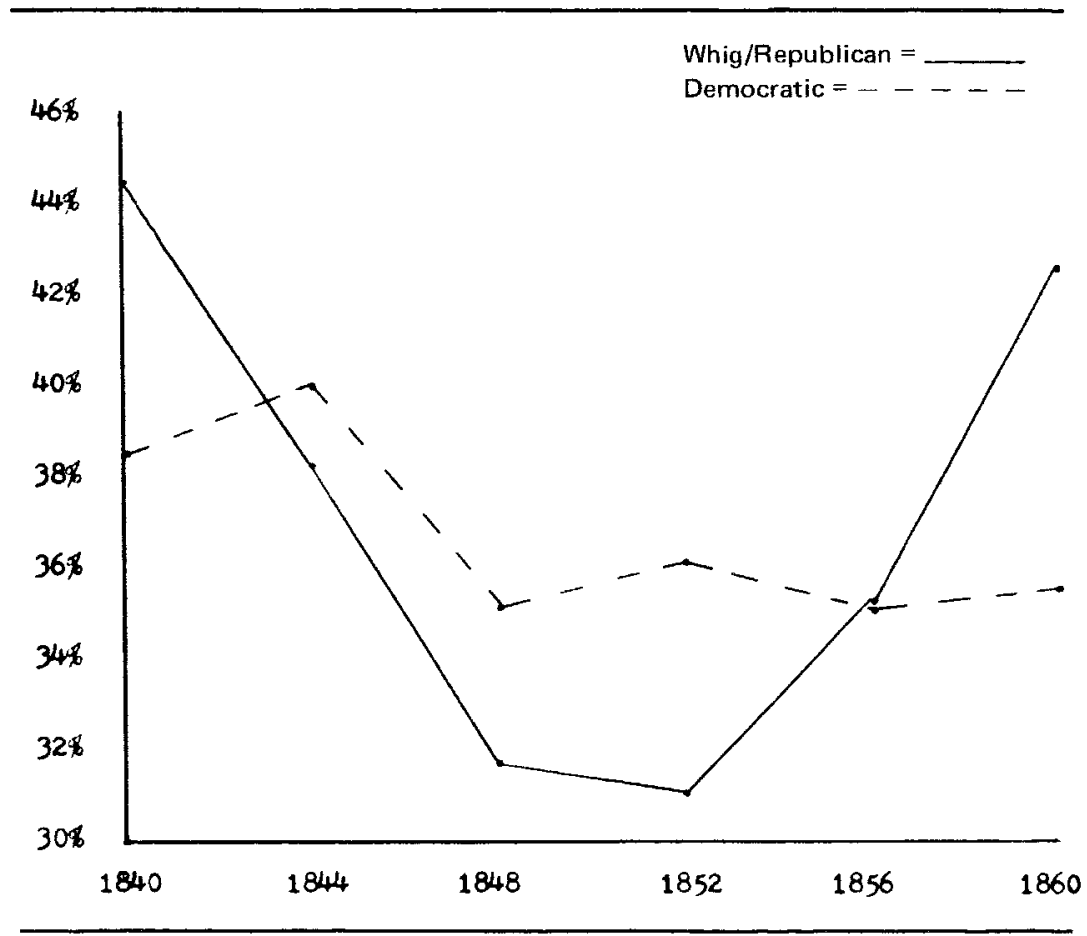

Figure 1: Estimated Porportion of Eligible Electorate Casting Whig/Republican or Democratic Ballots in Presidential Elections in the Four Midwestern States, 1840-1860 
returns suggest, then, that the Democratic voting support did not suffer a decline with the intrusion of the slavery extension issue into national politics in 1854 .

The regional percentages could, of course, be masking considerable volatility among the individuals supporting the Democracy during this period. Perhaps the defection of some Democrats to the Republican party was counterbalanced by a swing to the Democratic party by many disaffected ex-Whigs. To assess whether individuals voting Democratic in 1852 persisted in voting for that party after the emergence of the Republican party, estimates for the proportion of Pierce voters who cast Buchanan ballots were obtained by regressing the 1856 Democratic turnout on the 1852 Democratic turnout. If the Democratic constituency within the voting public indeed crumbled, one would expect that a rather low percentage of 1852 Democrats voted Democratic in 1856.

The estimates presented in Table 1 indicate that $90 \%$ of the 1852 Democrats in Illinois and Indiana repeated that choice in 1856 and that more than $60 \%$ and $70 \%$ of them did so in Michigan and Ohio, respectively. Apparently, only about a third of the 1852 Democratic voters throughout the Midwest failed to support the party in 1856. Did this comprise an extraordinarily large decline in support? One way of answering this question is to examine the patterns in voting Democrat in successive elections estimated for the preslavery-issue period. The first row in Table 2 presents the average for the proportion of people casting Democratic ballots in three pairs of Presidential elections (1840-1844, 1844-1848, 1848-1852) during the Whig-Democratic party system. The stability in the Democratic constituency between two elections during the stressful period of the mid-1850s compares favorably with the persistence in voting Democrat estimated for the 1840-1852 era, although the party fared less well in Ohio in this regard. According to the estimates, an average of $81 \%$ of the Democratic voters in the Midwest cast Democratic ballots in successive Presidential elections during the 1840s as compared 
TABLE 1

Estimated Proportion of Democratic Voters Casting Democratic Ballots in Subsequent Election

\begin{tabular}{|c|c|c|c|c|c|}
\hline Estimates for: & I111nois & Indiana & Michigan & Ohio & Region \\
\hline $\begin{array}{l}1852 \text { Democratic Voters } \\
\text { Casting Democratic } \\
\text { Ballots in } 1856\end{array}$ & $100 \%$ & $96 \%$ & $62 \%$ & $70 \%$ & $82 \%$ \\
\hline $\begin{array}{l}1856 \text { Democratic Voters } \\
\text { Casting Democratic } \\
\text { Ballots in } 1860\end{array}$ & $98 \%$ & $83 \%$ & $72 \%$ & $100 \%$ & $88 \%$ \\
\hline
\end{tabular}

TABLE 2

Average for the Estimated Proportion of Democratic Voters

Casting Democratic or Whig Ballots in Subsequent

Presidential Election, 1840-1852

Estimates for:

Illinois Indiana Michigan Ohio Region

Democratic Voters

Casting Democratic

Ballots

$82 \%$

$84 \%$

$62 \% \quad 96 \%$

$81 \%$

Democratic Voters

Casting Whig Ballots

$4 \%$

$4 \%$

$16 \% \quad 6 \%$

$7 \%$

with an average of $82 \%$ for the 1852-1856 elections. Evidently, the Democratic constituency did not disintegrate under the impact of the slavery controversy. Instead, the party apparently lost the usual number of people who failed to repeat their Democratic vote and retained the support of the usual number of voters who normally cast Democratic ballots in successive elections. At the individual level, the slavery extension issue did not seem to affect the Democratic constituency. 
THE REALIGNMENT:

THE FLOW TO THE REPUBLICANS

The swing in the balance of power during this period must be due to a flow of votes to the major opposition to the Democratic party, the new Republican party, rather than an ebbing of disaffected voters from the Democracy. A plot of the Republican turnout for each state reveals that the timing of the influx differed. The Republicans acquired a high proportion of the eligible electorate immediately with the 1856 campaign in Michigan, but experienced a distinct surge of support in 1860 in Illinois, Indiana, and Ohio (see Figure 2). Examination of these phenomena offers insights into the realigning process.

\section{$1852-1856$}

What were the political backgrounds of those people who cast Republican ballots in 1856 ? Surely, one would expect that many 1852 Free Soil voters would support the Republican ticket in 1856. The Free Soil party was organized in 1848 to prevent slavery from being implanted in the territories wrested from Mexico. When the Democratic leadership unexpectedly embraced a pro-slavery position in 1854, many Northern politicians quickly adopted Free Soilism as their own, but under the Republican banner. With Free Soilism as the heart of Republicanism, and with many Free Soil politicians holding prominent positions in the new party, a staunch Free Soiler could readily support the Republican party. Presumably, the same political views which prompted his Free Soil vote in 1852 would lead him to vote Republican in 1856. This interpretation predicts, then, that a large proportion of the 1852 Free Soil voters would vote for the Republican slate in 1856 .

Testing this hypothesis entails estimating the proportion of Free Soil voters who voted Republican in 1856 with the ecological regression procedure. If the Free Soilers did tend to move into the Republican party, then the proportion of Free 
Soil voters casting Republican ballots should exceed the proportion of those who did not. The estimates presented in the first row of Table 3 indicate that more than $100 \%$ of the 1852 Free Soil voters supported the Republican slate in 1856. This is, of course, impossible. The ecological regression might have produced these excessively high estimates because the procedure is insufficiently precise to handle the small percentages involved with the Free Soil turnout variable. Only about $5 \%$ of the eligible Midwestern electorate estimated for 1852 voted for the Free Soil party, while over $35 \%$ of the eligible electorate in 1856 cast Republican ballots. However, the estimates do suggest that a large proportion of the 1852 Free Soil voters moved into the Republican ranks in 1856.

The Republican party's leadership cadre contained a surprisingly large number of ex-Democrats. Several Republican Senators and governors elected during the 1850s had defected from the Democracy. For example, four members of Lincoln's first cabinet (Blair, Cameron, Chase and Welles) were Democratic defectors. This strong Democratic presence in the Republican elite has led some historians to contend that a sizable proportion of the Democratic rank-in-file also moved into the Republican fold. Although at least one historian has cautioned against inferring like behavior for politicians and electorate (Stoler, 1940), political studies of the period attribute considerable importance to the influx of ex-Democratic voters into the Republican coalition.

\section{TABLE 3}

\section{Estimated Proportion of 1852 Electoral Groups} Casting Republican Ballots in 1856

\begin{tabular}{|c|c|c|c|c|c|}
\hline Estimates for: & Illinois & Indiana & Michigan & $\underline{\text { Ohio }}$ & Region \\
\hline $\begin{array}{l}1852 \text { Free Soil Voters } \\
1852 \text { Democratic Voters } \\
1852 \text { Whig Voters } \\
1852 \text { Non-Voters }\end{array}$ & $\begin{array}{r}100 \% \\
0 \% \\
53 \% \\
23 \%\end{array}$ & $\begin{array}{r}100 \% \\
4 \% \\
80 \% \\
0 \%\end{array}$ & $\begin{array}{r}100 \% \\
28 \% \\
63 \% \\
50 \%\end{array}$ & $\begin{array}{r}100 \% \\
12 \% \\
52 \% \\
0 \%\end{array}$ & $\begin{array}{r}100 \% \\
11 \% \\
62 \% \\
18 \%\end{array}$ \\
\hline
\end{tabular}


This point of view can be tested by considering the estimates for the proportion of 1852 Democratic voters who cast their 1856 ballots for the Fremont ticket. Table 1 suggests that most 1852 Democrats continued to vote Democrat in the next Presidential election, but about a fifth did not. If they moved as a group behind the Republican banner, then they would have comprised a sizable proportion of the new party's voting strength. The estimates found in the second row of Table 3 are derived from the coefficients computed by regressing the 1856 Republican turnout upon the 1852 Democratic turnout. The percentages estimated by the regression vary somewhat across the four states. The highest estimate was calculated for Michigan where perhaps $28 \%$ of the people voting Democrat in 1852 voted Republican in 1856 . The rates were far lower in the more populous states, however. On the whole, the estimates suggest that only about $11 \%$ of the 1852 Democratic voters supported the Republican party in 1856 across the Midwest.

Whether the defection of about $11 \%$ of the Midwestern Democratic voters of 1852 to the 1856 Republican ticket signified a marked departure in behavior can be assessed by examining the proportion of Democratic voters in elections during the 1840-1852 period who subsequently voted Whig. The second row in Table 2 presents the average for the three pairs of Presidential elections (1840-1844, 1844-1848, 1848-1852) for the four Midwestern states.

Throughout the dozen years of the Whig-Democrat two-party system following 1840 , a small percentage of the Democratic voters of one Presidential election would cast a ballot for the Whig opposition in the next campaign. That is, normally one would find about $10 \%$ of the Democratic voters voting for the opposition in the following election. This defection rate is on the same low level of magnitude as the proportion of 1852 Democratic voters who defected to the Republicans in 1856 . In light of this general pattern, the movement of a small proportion of 1852 Democratic voters to the Republican slate 
in 1856 cannot be viewed as a crucial new element in producing the realignment.

Third, one might suppose that a large number of former Whig voters moved into the Republican party in 1856 . For one thing, the positions adopted by the Republican platform on economic issues such as a transcontinental railroad and government financed improvement of rivers and harbors were consonant with those advanced by the Whigs over the preceding decade or two. Moreover, many of the leaders in the new Republican party were ex-Whig politicians. Important aspects of the Republican party, then, seemingly would appear familiar and unobjectionable to Whig voters facing a new party system in 1856. Certainly, the Republican party would provide a more comfortable political home for ex-Whigs than would their old adversary, the Democracy.

Whether many Whigs seemed to move into the Republican party can be answered by examining the estimates for the percent of 1852 Whigs who voted Republican in 1856. The estimates in the third row of Table 3 are obtained by regressing the 1856 Republican turnout on the 1852 Whig turnout. The estimates suggest that well over half of the 1852 Whigs cast Republican ballots in 1856-indicating a strong pro-Republican movement on the part of many rank-and-file Whigs into the new party's electoral coalition.

How does the rate at which Whigs flowed into the Republican party compare with the stability in the Whig vote during the preceding decade? Table 4 presents the average for the proportion of Whig voters casting Whig ballots in the next

TABLE 4

Average for the Estimated Proportion of Whig Voters

Casting Whig Ballots in Subsequent

Presidential Elections, 1840-1852

$\frac{\text { Illinois }}{77 \%} \underset{83 \%}{\text { Indiana }} \frac{\text { Michigan }}{66 \%} \frac{\text { Ohio }}{81 \%} \frac{\text { Region }}{77 \%}$


Presidential election for the states in the three pairs of Presidential elections between 1840 and 1852 (1840-1844, 1844-1848, 1848-1852). The level of stability of the Whig vote in Indiana and Michigan during the 1840-1852 period was on the same order of magnitude as the proportion of the 1852 Whigs who cast Republican ballots in 1856. That is, the Republicans attracted the support of the same proportion of 1852 Whig voters as the Whig politicians might have expected if their party had survived to contest the 1856 campaign. In Illinois and Ohio, however, the proportion of 1852 Whigs voting Republican fell between $20 \%$ and $30 \%$ below the average proportion of people casting Whig ballots in successive Presidential elections. These important differences notwithstanding, in each state more than half of the people supporting the Whig ticket in its final national campaign apparently moved into the Republican ranks in 1856.

The final possible source for Republican votes in 1856 was the group of people who abstained in 1852 . These citizens are usually overlooked in the historical literature, perhaps because nonvoting is viewed as an occasional lapse on the part of normally active voters. However, elsewhere I show that the electorate apparently contained a group of people who tended not to vote in successive elections (Shortridge, 1974; n.d.). This group of nonvoters seems to have been uninterested in the issues and personalities present in the political arena during the second American party system. Perhaps the Republican crusade to prevent the extension of slavery into the territories aroused the interest of those who regularly abstained. Specifically, did the nonvoters in the Scott-Pierce campaign move to the support of the Fremont ticket in 1856? This question can be answered by examining the estimates for the proportion of 1852 abstainers who cast Republican ballots in 1856 .

Estimates presented in the fourth row of Table 3 reveal that the strength of the pro-Republican movement by the 1852 abstainers varied among the four states. These estimates suggest that very few 1852 nonvoters turned out for Fremont in 
Indiana and Ohio and only a small proportion (23\%) did so in Illinois. A more sizable proportion of 1852 abstainers were estimated to have supported the Republicans in 1856 in Michigan. The marked difference in behavior across the four states suggests that the nonvoters did not make a consistently strong contribution to the 1856 Republican vote.

A few general patterns in the flow of the vote to the Republican party in 1856 emerged from the estimates produced by the analysis. First of all, Democratic voters apparently did not cross over to the Republican party in unprecedented numbers. The relatively small proportion of 1852 Democrats casting Republican ballots in 1856 was only slightly higher than the normal proportion of Democratic voters crossing over to the Whig party during the $1840-1852$ period. Second, in the three more populous states (Illinois, Indiana, and Ohio), only a small proportion of those who abstained in 1852 supported the Republican ticket in 1856. However, in Michigan, where the Republican party received a substantially higher turnout than did the Whigs four years earlier $(45.7 \%$ and $28.6 \%$, respectively-see Figure 2), perhaps one-half of the 1852 abstainers cast Republican ballots in 1856. Since about $30 \%$ of the Michigan electorate abstained in 1852 , those nonvoters who subsequently supported Fremont comprised an important element in the Republican constituency in Michigan. Third, well over half of the 1852 Whig voters in the Midwest evidently cast Republican ballots in 1856 . The Whig party received the votes of about $31 \%$ of the 1852 electorate in the region-the large proportion of this group aligning itself behind the Republican banner in 1856 represented an important segment of the new party's Midwestern electoral coalition. Finally, the Free Soil voters evidenced the strongest propensity to vote Republican. Although they comprised only about $5 \%$ of the 1852 Midwest electorate, they appear to have moved virtually en masse into the Republican ranks in 1856. 


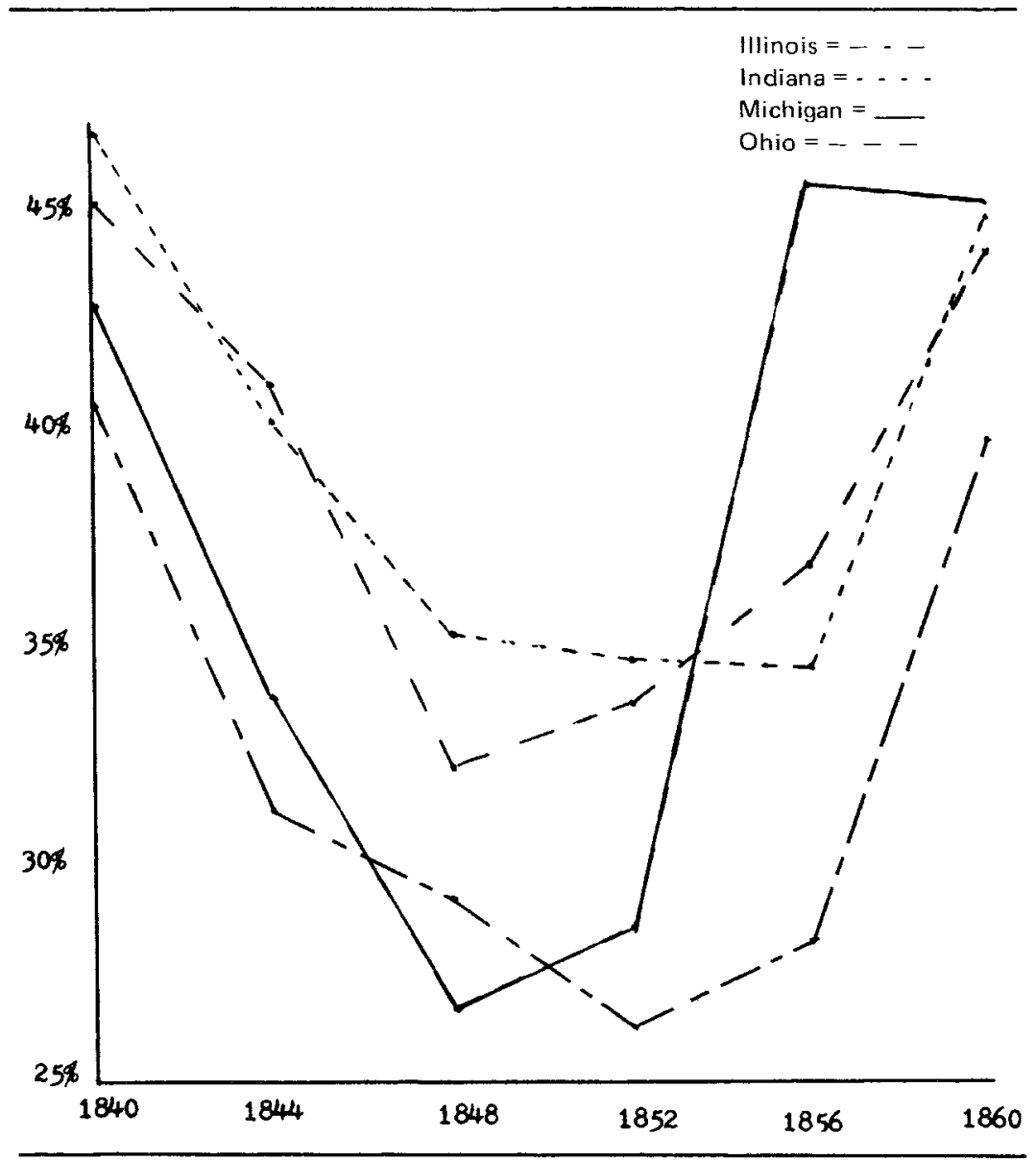

Figure 2: Estimated Proportion of Eligible Electorate Casting Whig or Republican Ballots in Each State, in Presiden tial Elections, 1840-1860

$1856-1860$

For the three more populous Midwestern states-Illinois, Indiana, and Ohio-the surge of voters to the Republican party which assured its hegemony over the region did not occur until the 1860 election. This section examines the flow of the vote in 
the last half of the decade in these states to complete the inquiry into the 1850 s realignment. The analysis of election data for the 1856-1860 period suggests that the Republican vote in 1860 consisted of two distinguishable groups: a very reliable core comprised of those people who voted for Fremont in 1856 and a group of voters who were outside the Republican fold in 1856 but joined the Republican constituency in 1860 .

Turning first to the core voters, the first row in Table 5 presents the estimates for the proportion of 1856 Republican voters casting Republican ballots in 1860 . The estimates suggest that a very high percentage of the 1856 Republican voters persisted in that choice in 1860 . In each of these three states, more than $90 \%$ of the 1856 Republican voters voted for Lincoln. Apparently, the 1856 Republican voters provided the party with a sizable reliable voting bloc upon which to build their winning electoral coalition.

Whence the voters shifting to the Republican party in 1860 ? One possibility is that a significant number of former Democratic voters crossed over to the Republican party. Although most of those people who voted for Buchanan in 1856 also apparently supported Douglas in 1860 (see Table 1), some did not, and this latter group might have moved to the Republican fold. One might speculate that a number of Democrats became disaffected with their party's intransigence on the slavery issue and became dismayed with the events in Kansas and with the Dred Scott decision. Their confidence in the Democracy might also have been undermined by the Southern influence in the Buchanan Administration manifested in the vetoes of homestead bills and other economic programs important to the North (Van Deusen, 1965: 5-6, 12). One might conclude that they belatedly broke with their party and voted for Lincoln.

This delayed-Democratic-defection explanation for the surge in the Republican strength observed in 1860 can be tested by examining the estimates for the proportion of 1856 Buchanan voters casting Lincoln ballots presented in the second row of Table 5. These estimates indicate that ex-Democratic voters 
TABLE 5

Estimated Proportion of 1856 Electoral Groups Casting Republican Ballots in $\mathbf{1 8 6 0}$

Estimates for:

\begin{tabular}{|c|c|c|c|}
\hline I11inois & Indiana & Ohio & Region \\
\hline $\begin{array}{r}91 \% \\
0 \% \\
83 \%\end{array}$ & $\begin{array}{r}90 \% \\
5 \% \\
55 \%\end{array}$ & $\begin{array}{r}95 \% \\
0 \% \\
65 \%\end{array}$ & $\begin{array}{r}92 \% \\
2 \% \\
67 \%\end{array}$ \\
\hline
\end{tabular}

made only a modest contribution to the 1860 Republican surge; only a small proportion of the people voting Democrat in 1856 in these states switched their vote to the Republican ticket in 1860. The surge to the Republicans observed between 1856 and 1860 is not attributable to a conversion of a sizable group of people who voted Democrat in 1856 .

Another possible source for Republican support lies in the 1856 American party supporters. In 1856, Millard Fillmore led a political party organized to advance nativist principlesnotably restricting public office to native-born citizens and tightening the immigration laws. This party, the American party, attracted the votes of a considerable number of the estimated eligible electorate in Illinois, Indiana, and Ohio $(11.1 \%, 8.3 \%$, and $5.5 \%$, respectively). The American party did not contest the 1860 election in the Midwest. Consequently, if a high proportion of its supporters cast their ballot for Lincoln in 1860 , the nativist flow into the Republican party could have provided a significant component to the surge in Republican turnout for that election.

This explanation can be assessed by examining the estimates for the proportion of 1856 nativist voters who flowed into the Republican party during the 1860 election. The estimates, presented in the third row of Table 5, suggest that more than $60 \%$ of the 1856 nativist voters switched to the Republican party for the 1860 election. An important element in the surge in the 1860 Republican vote apparently stemmed from large numbers of 1856 American party voters crossing over to the Lincoln ticket. 
TABLE 6

Estimated Proportion of 1856 Non-Voters Casting Republican or Democratic Ballots in 1860

\begin{tabular}{lcccc}
\hline Estimates for: & Illinois & Indiana & Ohio & Region \\
\cline { 2 - 3 } $\begin{array}{l}1856 \text { Non-Voters Casting } \\
\text { Republican Ballots }\end{array}$ & $18 \%$ & $42 \%$ & $19 \%$ & $26 \%$ \\
$\begin{array}{l}1856 \text { Non-Voters Casting } \\
\text { Democratic Ballots }\end{array}$ & $15 \%$ & $39 \%$ & $12 \%$ & $22 \%$ \\
\hline
\end{tabular}

The final source for additional Republican voters during the Lincoln campaign is comprised of those who abstained in 1856. Possibly, the Republicans succeeded in mobilizing considerable numbers of normally apathetic citizens during the 1860 campaign because of the increased furor over the slavery issue. The first row in Table 6 presents the estimates for the proportion of 1856 nonvoters who subsequently cast their ballots for Lincoln. These estimates indicate that about $40 \%$ of the 1856 nonvoters turned out for Lincoln in Indiana and about $20 \%$ of them did so in Illinois and Ohio.

However, in 1860 the Democracy also received the votes of large numbers of 1856 abstainers. As the second row in Table 6 indicates, the pro-Democrat movement across the states mirrored the pro-Republican shift. The proportion of 1856 nonvoters casting Democratic ballots in 1860 was almost the same in each state as the proportion casting Republican ballots. This suggests that the Republicans' strongly anti-slavery position and its economic policies did not have a more potent saliency to the nonvoting group within the Midwestern electorate than the Democratic positions on these issues.

However, in 1860 the Republicans apparently attracted a greater proportion of the 1856 nonvoting group than the Whigs were accustomed to attracting from the nonvoters during the second American party system. Table 7 presents the proportion of abstainers voting Whig or Democrat in the subsequent election for the three pairs of Presidential elections in the 1840 
TABLE 7

Estimated Proportion of Non-Voters Casting

Whig or Democratic Ballots in Subsequent

Presidential Elections, 1840-1852

\begin{tabular}{lcccc}
\hline Estimates for: & Illinois & Indiana & Ohio & Region \\
$\begin{array}{l}\text { Non-Voters Casting } \\
\text { Whig Ballots }\end{array}$ & $8 \%$ & $8 \%$ & $9 \%$ & $8 \%$ \\
$\begin{array}{l}\text { Non-Voters Casting } \\
\text { Democratic Ballots }\end{array}$ & $13 \%$ & $18 \%$ & $13 \%$ & $15 \%$ \\
\hline
\end{tabular}

to 1852 period. The Republicans apparently mobilized about twice as many people from the abstaining group in 1860 as the Whigs usually did in the earlier period. On the other hand, the movement by 1856 nonvoters to the Democratic slate in 1860 merely reflected a long-term pattern in which the Democrats normally garnered the votes of about $15 \%$ of the people who abstained in the preceding election.

A general pattern emerges in the surge in Republican strength between 1856 and 1860 observed in Illinois, Indiana, and Ohio. The Republican vote in 1860 seems to have contained two distinct elements. The first element was a solid core consisting of those people who cast Republican ballots in 1856. About $33 \%$ of the electorate in these three states voted Republican in 1856 and more than $90 \%$ of them apparently supported Lincoln in 1860 . The second element was the shift to the Republican party by people who had not supported the party in 1856 . The Republicans attracted votes principally from those who abstained in 1856 and those who followed the nativist banner. Evidently, very few of those voting Democratic in 1856 crossed over to the Republican party and voted for Lincoln. The 1856 nonvoters, who comprised about $23 \%$ of the electorate at that time, exhibited slightly pro-Republican leanings in 1860. Perhaps $25 \%$ of them switched to the Republican party in 1860 while a slightly lower proportion (about 20\%) supported the Democracy. A stronger movement to the Republican party was 
apparently made by the people who voted nativist in 1856-the American party garnered about $7 \%$ of the electorate in the Midwest. According to the estimates, about two-thirds of the 1856 American party voters in these three states supported Lincoln in 1860. In general, then, the people who voted Democrat or Republican in 1856 tended to persist in that choice in 1860. The surge to the Republicans during the Lincoln campaign evidently came in part from some of the 1856 nonvoters, but principally from the shift of a large proportion of the 1856 nativist party voters.

\section{CONCLUSIONS}

The realignment process in the Midwest during the 1850 s varied somewhat among the four most populous states. In Michigan, the major shift to the Republicans occurred in one stage; in 1856 , most of the Free Soilers, Whigs, and a large proportion of the nonvoters of the 1852 campaign moved into the Republican ranks. In Illinois, Indiana, and Ohio, however, two distinct stages emerged in the movement of the electorate to the Republican banner. According to the estimates, the 1852 to 1856 stage consisted largely of the fusion of most Free Soilers and a sizable proportion of Whig voters of the 1852 election into a Republican voting bloc in 1856. The constituency resulting from this fusion made the Republican party a strong competitor of the Democrats in these states but did not result in dominance. Hegemony came to the Republican party with the 1860 campaign when the solid bloc of Fremont voters was apparently augmented by most of the people voting nativist and some of those who abstained in 1856 .

The shift in the balance of power from the Democracy to the Republicans during the 1850 s in these states profoundly altered the political life of the region and the nation. Political discourse 
during this period was preoccupied with the slavery extension issue, and doubtless this controversy aroused deep emotions and antagonisms. Yet the voting choices made by the mass electorate seem to have been remarkably stable. Most Democrats apparently resisted the blandishments of the Republican and nativist politicians and continued to support the Democracy. Only a small proportion of the people who abstained in 1852 was estimated to have voted Republican or nativist in 1856, despite the increasing furor over slavery extending into the distant territories and the dire warnings about immigrants acquiring political power in their own communities. The instability seems to have centered among the adherents of the now extinct Whig party. Yet, few Whigs crossed over to their old adversaries, the Democrats, and few seemed to lose interest in politics and stop voting. By 1860 , most of the 1852 Whigs were apparently casting Republican ballots.

The Republican politicians benefited from the fracturing of the Whig-Democratic party system along two fault lines. The fault which ultimately defined the polarity of the new party system appeared in national politics during the 1840 s with the organization of an anti-slavery-extension party, Free Soil, in the North. When the Democratic party's leadership blundered over the Kansas-Nebraska bill in 1854, aspiring politicians in the North were able to create the new Republican party which attracted the votes of the Free Soilers and most of the Whigs. In the confusion produced by the death of the Whig party, other politicians sought to exploit the second fault; they attempted to interest voters in a nativist party, but attracted the support of only a few. However, the general movement on the part of the 1856 nativist voters toward the Republican party in 1860 , plus the support of some of those who had previously abstained, enabled Lincoln to swamp the Democratic slate in the region. The 1850 s realignment, then, seems to have entailed two processes: the 1856 fusion of Free Soil voters and many Whigs 
into a solid core of Republican voters; and the movement of many 1856 nativist voters and some 1856 nonvoters into the Republican ranks in 1860 .

\section{NOTES}

1. These statistics are drawn from Walter Dean Burnham (1955). The North considered here encompasses New England, New York, New Jersey, Pennsylvania, Ohio, Michigan, Indiana, Illinois, Wisconsin, and Iowa.

2. For a discussion of the temporal span of a realignment, see V. O. Key, Jr. $(1955,1959)$ and Duncan Macrae, Jr. and James A. Meldrum (1960).

3. The data comprising these variables were made available (in part) by the Inter-University Consortium for Political Research. The Consortium bears no responsibility for either the analysis or interpretations reported here.

4. The equation for this multiple regression is: $\bar{Y}_{j}=b_{0}+b_{1} \bar{X}_{j}+b_{2} \bar{X}_{j}+E_{j}$.

\section{REFERENCES}

ALKER, H, R., Jr. (1969) Mathematics and Politics. London: Macmillan.

BELKNAP, G. and A. CAMPBELL (1951-1952) "Political party identification and at titudes toward foreign policy." Public Opinion Q. 15 (Winter): 601-623.

BENSON, L. (1967) The Concept of Jacksonian Democracy: New York as a Test Case. New York: Atheneum.

BERELSON, B. R., P. F. LAZARSFELD, and W. McPHEE (1954) Voting. Chicago: Univ. of Chicago Press.

BOYD, L. H. (1971) "Multiple level analysis with complete and incomplete data." Ph.D. dissertation, University of Michigan.

BURNHAM, W. D. (1970) Critical Elections and the Mainstrings of American Politics. New York: W. W. Norton.

_-_- (1955) Presidential Ballots, 1836-1892. Baltimore, Md.: Johns Hopkins Press.

-_-, J. M. CLUBB, and W. H. FLANIGAN (1973) "Partisan realignment: a systemic perspective." Paper presented to the Conference on Popular Voting Behavior sponsored by the Mathematical Social Science Board, June.

CAMPBELL, A., G. GURIN, and W. E. MILLER (1954) The Voter Decides. Evanston, Ill.: Row, Peterson. 
CAMPBELl, A., P. CONVERSE, W. MILlER, and D. STOKES (1960) The American Voter. New York: John Wiley.

CONVERSE, P. E. (1969) "Survey research and the decoding of patterns in ecological data," pp. 459-485 in M. Dogan and S. Rokkan (eds.) Quantitative Ecological Analysis in the Social Sciences. Cambridge, Mass.: MIT Press.

--- and G. DUPEUX (1967) "DeGaulle and Eisenhower: the public image of the victorious general," pp. 292-345 in A. Campbell et al., Elections and the Political Order. New York: John Wiley.

CONVERSE, P. E., A. CAMPBELL, W. E. MILLER, and D. E. STOKES (1961) "Stability and change in 1960: a reinstating election." Amer. Pol. Sci. Rev. 55 (June): 269-280.

DUNCAN, O. D. and B. DAVIS (1953) "An alternative to ecological correlation." Amer. Soc. Rev. 18 (December): 665-666.

ERSHKOWITZ, H. and W. G. SHADE (1971) "Consensus or conflict? Political behavior in the state legislatures during the Jacksonian Era." J. of Amer. History 57 (December): 591-621.

EULAU, H. and P. SCHNEIDER (1956) "Dimensions of political involvement." Public Opinion Q. 20 (Spring): 128-142.

FILLER, L. (1960) The Crusade Against Slavery, 1830-1860. New York: Harper \& Row.

FONER, E. (1970) Free Soil, Free Labor, Free Men: The Ideology of the Republican Party Before the Civil War. New York: Oxford Univ. Press.

FORMISANO, R. P. (1971) The Birth of Mass Political Parties, 1827-1860. Princeton, N.J.: Princeton Univ. Press.

GOODMAN, L. A. (1959) "Some alternatives to ecological correlation." Amer. J. of Sociology 64 (May): 610-625.

-. (1953) "Ecological regressions and the behavior of individuals." Amer. Soc. Rev. 18 (December): 663-664.

KEY, V. O., Jr. (1959) "Secular realignment and the party system." J. of Politics 21 (May): 198-210.

-- (1955) "A theory of critical elections." J. of Politics 17 (February): 1-18.

-- (1953) Politics, Parties, and Pressure Groups. New York: Thomas Y. Crowell.

LOWI, T. H. (1967) "Party, policy, and constitution in America," pp. 238-276 in W. N. Chambers and W. D. Burnham (eds.) The American Party Systems: Stages of Political Development. New York: Oxford Univ. Press.

MACRAE, D., Jr. and J. A. MELDRUM (1960) "Critical elections in Illinois: 1880-1958." Amer. Pol. Sci. Rev. 54 (September): 669-683.

NEVINS, A. (1947) Ordeal of the Union: A House Dividing, 1852-1857. New York: Charles Scribner's Sons.

ROBINSON, W. S. (1950) "Ecological correlations and the behavior of individuals." Amer. Soc. Rev. 15 (June): 351-357.

SHORTRIDGE, R. M. (1974) "Voting patterns in the American Midwest, 1840-1 872." Ph.D. disser tation, University of Michigan.

--- (n.d.) "Democracy's golden age? Voter turnout in the Midwest, 1840-1872." (typescript)

SMITH, E. B. (1967) The Death of Slavery: The United States, 1837-1865. Chicago: Univ. of Chicago Press. 
STOLER, M. C. (1940) "The Democratic element in the new Republican Party in Indiana." Indiana Magazine of History 36 (September).

SUNDQUIST, J. L. (1973) Dynamics of the Party System. Washington, D.C.: The Brookings Institution.

VAN DEUSEN, G. G. (1965) "Why the Republican Party came to power," in G. H. Knoles (ed.) The Crisis of the Union, 1860-1861. Baton Rouge, La.: Louisiana State Univ. Press.

Ray M. Shortridge has a Ph.D. in history and specializes in A merican electoral behavior in the nineteenth century. He is currently a Research Associate in the University of Michigan Law School. 